\title{
PENELITIAN ADMINISTRATIF DI PENGADILAN TATA USAHA NEGARA
}

\author{
NAMA : Randhy Astira Latuconsina \\ EMAIL : Randhylatuconsina@gmail.com \\ No Bp : (1910003600303) \\ Universitas Ekasakti Padang \\ Kelas : $3 \mathrm{H} 5$
}

\section{BAB I}

PENDAHULUAN

\section{1 latar belakang}

Di bidang perdata dan tata usaha negara, Kejaksaan dengan kuasa khusus dapat bertindak baik di dalam maupun di luar pengadilan untuk dan atas nama negara atau pemerintah(vide Pasal 30 ayat (2) Undangundang Nomor 16 Tahun 2004 tentang Kejaksaan RI). Selain itu Kejaksaan juga dapat memberikan pertimbangan dalam bidang hukum kepada instansi pemerintah lainnya (vide Pasal 34 UU Nomor 16 Tahun 2004).

Jaksa Agung Muda Perdata dan Tata Usaha Negara (JAM DATUN) adalah unsur pembantu pimpinan dalam melaksanakan tugas dan wewenang Kejaksaan di bidang perdata dan tata usaha negara (vide Pasal 23 ayat (1) dan Pasal 24 ayat (1) Peraturan Presiden (Perpres) Nomor 38 Tahun 2010 tentang Organisasi dan Tata Kerja Kejaksaan RI sebagaimana diubah dengan Perpres Nomor 29 Tahun 2016). Salah satu tugas dan fungsi dari JAM DATUN adalah mewakili negara dan pemerintah dalam hal ini badan atau pejabat tata usaha negara di dalam dan di luar pengadilan tata usaha negara dalam rangka menjaga kewibawaan negara/pemerintah.

Tugas dan fungsi ini dilaksanakan oleh Direktorat Tata Usaha Negara pada JAM DATUN, Asisten Perdata dan Tata Usaha Negara cq Kepala Seksi Tata Usaha Negara untuk tingkat Kejaksaan Tinggi dan Kepala Seksi DATUN untuk tingkat Kejaksaan Negeri.Pendidikan dan Pelatihan Pembentukan Jaksa (PPPJ) dimaksudkan untuk menyiapkan jaksa-jaksa yang siap bertugas dalam rangka menjalankan tugas dan fungsi Kejaksaan RI, baik di bidang pidana, perdata dan TUN, dan tuga usaha negara, sehingga pada saatnya nanti para peserta PPPJ akan siap menghadapi tugas beracara di peradilan tata usaha negara, mulai dari tingkat pertama sampai tingkat kasasi, mulai dari menyusun surat jawaban sampai dengan menyusun memori kasasi atau bahkan memori peninjauan kembali.

Untuk update informasi, di dalam modul ini juga akan dibahas mengenai ketentuan-ketentuan baru dalam hukum acara tata usaha negara antara lain permohonan untuk mendapatkan putusan dan/atau Tindakan Badan atau Pejabat Pemerintahan (positif fiktif) yang diatur dalam Peraturan Mahkamah Agung (PERMA) 
Nomor 5 Tahun 2015 tentang Pedoman Beracara Untuk Memperoleh Putusan Atas Penerimaan Permohonan Guna Mendapatkan Keputusan dan/atau Tindakan Badan atau Pejabat Pemerintahan. Selain itu juga akan dibahas kewenangan baru dari Pengadilan Tata Usaha Negara untuk memutus ada atau tidaknya unsur penyalahgunaan wewenang yang dilakukan oleh Badan dan/atau Pejabat Pemerintahan sebagaimana diatur dalam PERMA Nomor 4 Tahun 2015 tentang Pedoman Beracara Dalam Penilaian unsur Penyalahgunaan Wewenang.

1.2 rumusan masalah

1. Apa itu Penelitian administrasi di Kepaniteraan Pengadilan Tata Usaha Negara

2. Pengertian Upaya administratif

3. Dasar Hukum Upaya Administratif

\section{BAB II}

\section{PEMBAHASAN}

\subsection{Penelitian administrasi di Kepaniteraan Pengadilan Tata Usaha Negara}

Petugas yang berwenang untuk melakukan penelitian administratif adalah Panitera, Wakil Panitera dan Panitera Muda Perkara, sesuai pembagian tugas yang diberikan. Penelitian administratif dilakukan secara formal tentang bentuk dan isi gugatan sesuai pasal 56, dan tidak menyangkut segi materril gugatan. Namun demikian dalam tahap ni Panitera harus memberikan petunjuk-petunjuk seperlunya dan dapat meminta kepada pihak penggugat untuk memperbaiki gugatan yang dipandang perlu. Panitera tidak berhak menolak pendaftaran perkara tersebut dengan dalih apapun juga berkaitan dengan materi gugatan.

Setelah Penggugat membayar Uang Panjar Beaya Perkara, maka gugatan akan dilakukan pendaftaran nomor perkaranya dengan memasukan dalam Buku Register Perkara dan pada gugatan dibubuhi stempel dan tanggal pada sudut kiri gugatan. Selanjutnya berkas perkara gugatan tersebut oleh Panitera diteruskan diserahkan

kepada Ketua Pengadilan TUN untuk dilakukan Proses selanjutnya terhadap gugatan tersebut, antara lain dilakukan Dismissal Proses, diteliti apakah terdapat apakah permohonan penundaan

pelaksanaan Keputusan TUN yang digugat, apakah terdapat permohonan Penggugat untuk beracara cepat atau permohonan untuk beracara cuma-cuma.

2.2 Pengertian Upaya administratif

Menurut Penjelasan pasal 48 Undang-Undang No. 5 Tahun 1986 jo Undang-Undang No. 9 Tahun 2004 tentang Peradilan Tata Usaha Negara, upaya administratif adalah merupakan 
prosedur yang ditentukan dalam suatu peraturan perundang-undangan untuk menyelesaikan suatu sengketa Tata Usaha Negara yang dilaksanakan dilingkungan pemerintah sendiri (bukan oleh badan peradilan yang bebas), yang terdiri dari :

a. Prosedur keberatan;

b. Prosedur banding administratif;

Berdasarkan rumusan penjelasan pasal 48 tersebut maka upaya administratif merupakan sarana perlindungan hukum bagi warga masyarakat (orang perorangan/badan hukum perdata) yang terkena Keputusan Tata Usaha Negara (Beschikking) yang merugikannya melalui Badan/Pejabat Tata Usaha Negara dilingkungan pemerintah itu sendiri sebelum diajukan ke badan peradilan.

\subsection{Dasar Hukum Upaya Administratif}

Dalam pasal 48 Undang-Undang No. 5 Tahun 1986 jo Undang- Undang No. 9 Tahun 2004 tentang Peradilan Tata Usaha Negara, disebutkan sebagai berikut :

1) Dalam hal suatu Badan/Pejabat Tata Usaha Negara diberi wewenang oleh atau berdasarkan peraturan perundang-undangan untuk menyelesaikan secara administratif sengketa Tata Usaha Negara tertentu, maka sengketa Tata Usaha Negara tersebut harus diselesaikan melalui upaya administratif yang tersedia;

2) Pengadilan baru berwenang memeriksa, memutus, dan

menyelesaikan sengketa Tata Usaha Negara sebagaimana dimaksud ayat (1) jika seluruh upaya administratif yang bersangkutan telah digunakan.

3) BENTUK UPAYA ADMINISTRASI DAN CARA PENGUJIANNYA

Berdasarkan penjelasan pasal 48 Undang-Undang No. 5 Tahun 1986 jo Undang-Undang No. 9 Tahun 2004 tentang Peradilan Tata Usaha Negara, bentuk upaya administrasi ada 2 (dua) yaitu :

1. Banding administrasi;

2. Keberatan

1) Banding administrasi;

Apabila penyelesaian sengketa Tata Usaha Negara tersbut dilakukan oleh instasi lain dari Badan/Pejabat Tata Usaha Negara yang menerbitkan Keptusan Tata Usaha Negara yang bersangkutan.

Contoh :

- Keputusan Badan Pertimbangan Kepegawaian (BAPEK) berdasarkan No. 30 Tahun 1980 tentang Disiplin PNS;

- Keputusan Panitia Penyelesaian Perselisihan Perburuhan Pusat (P4P) berdasar Undang-Undang No. 22 Tahun 1957 tentang Penyelesaian Perburuhan dan Undang-Undang No. 12 Tahun 1964 tentang Pemutusan Hubungan Kerja di Perusahaan Swasta;

- Keputusan Gubernur, berdasar pasal 10 ayat (2) Undang-Undang Gangguan, Staasblad 1926 No. 226; 
- Keputusan Panitia Tenaga Kerja Migas di lingkungan Departemen Pertambangan bagi perusahaan minyak dan gas bumi (PERTAMINA);

- Komisi Banding Paten berdasarkan PP No. 31 Tahun 1995, sehubungan dengan adanya Undang-Undang No. 6 Tahun 1989 tentang Paten;

- Komisi Banding Merek berdasarkan PP No. 32 Tahun 1995, sehubungan dengan adanya Undang-Undang No. 19 Tahun 1992 tentang Merek;

-Majelis Pertimbangan Pajak sebagai banding administrasi perpajakan;

- Dengan berkembangnya perusahaan-perusahaan milik Negara dari PERJAN dan PERUM menjadi PERSERO (BUMN) tersebut membuat ketentuan sendiri tentang operasional, kepegawaian, dll.

\section{2). Keberatan ;}

Apabila penyelesaian sengketa Tata Usaha Negara tersebut harus dilakukan sendiri oleh Badan/Pejabat Tata Usaha Negara yang mengeluarkan Keputusan Tata Usaha Negara tersebut.

Contoh :

Pasal 27 Undang-Undang No. 9 Tahun 1994 tentang ketentuan-Ketentuan Umum Perpajakan;

Pemberian hukuman disiplin sedang dan berat (selain pemberhentian dengan hormat dan tidak dengan hormat bagi (PNS).

Pengujian (Toetsing) dalam upaya administrasi berbeda dengan pengujian di Peradilan Tata Usaha Negara. Di Peradilan Tata Usaha Negara pengujiannya hanya dari segi penerapan hukum sebagaimana ditentukan pasal 53 ayat (2) huruf (a) dan (b) Undang-Undang No. 9 Tahun 2004 tentang perubahan atas Undang-Undang No. 5 Tahun 1986 tentang Peradilan Tata Usaha Negara, yaitu apakah keputusan Tata Usaha Negara tersebut diterbitkan dengan bertentangan dengan peraturan perundang-undangan yang berlaku dan melanggar Asas-Asas Umum Pemerintah Yang Baik (AAUPB), sedangkan pada prosedur upaya administrasi, pengujiannya dilakukan baik dari segi penerapan hukum maupun dari segi kebijaksanaan oleh instansi yang memutus, sehingga pengujiannya dilakukan secara lengkap.

Sisi positif upaya administrasi yang melakukan penilaian secara lengkap suatu Keputusan Tata Usaha Negara baik dari segi Legalitas (Rechtmatigheid) maupun aspek Opportunitas (Doelmatigheid), para pihak tidak dihadapkan pada hasil keputusan menang atau kalah (Win or Loose) seperti halnya di lembaga peradilan, tapi denganpendekatan musyawarah. Sedangkan sisi negatifnya dapat terjadi pada tingkatobyektifitas penilaian karena Badan/Pejabat tata Usaha Negara yang menerbitkan Surat Keputusan kadang-kadang terkait kepentingannya secara langsung ataupun tidak langsung sehingga mengurangi penilaian maksimal yang seharusnya ditempuh. Tidak semua peraturan dasar penerbitan Keputusan Tata Usaha Negara mengatur mengenai upaya administrasi, oleh karena itu adanya ketentuan pasal 48 Undang-Undang No. 5 Tahun 1986 jo Undang-Undang No. 9 Tahun 2004 tentang Peradilan Tata Usaha Negara merupakan aspek prosedural yang sangat penting yang berkaitan dengan kompetensi atau wewenang untuk mengadii sengketa Tata Usaha Negara.

Berdasarkan Surat Edaran Mahkamah Agung RI No. 2 tahun 1991 tentang Petunjuk Pelaksanaan 
Ketentuan Dalam Undang-Undang No. 5 Tahun 1986 tentang Peradilan Tata Usaha Negara, disebutkan :

Yang dimaksud Upaya Adiministratif adalah :

a. Pengajuan surat keberatan (Bezwaarscriff Beroep) yang diajukan kepada Badan/Pejabat Tata Usaha Negara yang mengeluarkan Keputusan (Penetapan/ Beschikking) semula;

b. Pengajuan banding administratif (administratif Beroep)

yang ditujukan kepada atasan Pejabat atau instansi lain dari Badan/Pejabat Tata Usaha Negara yang mengeluarkan keputusan yang berwenang memeriksa ulang keputusan Tata Usaha Negara yang disengketakan.

a. Apabila peraturan dasarnya hanya menentukan adanya upaya administratif berupa peninjauan surat keberatan, maka gugatan terhadap Keputusan Tata Usaha Negara yang bersangkutan diajukan kepada pengadilan Tata Usaha Negara;

b. Apabila peraturan dasarnya menentukan adanya upaya adiministratif berupa surat keberatan dan atau mewajibkan surat banding administratif, maka gugatan terhadap Keputusan Tata Usaha Negara yang telah diputus dalam tingkat banding administratif diajukan langsung kepada Pengadilan Tinggi Tata Usaha Negara dalam tingkat pertama yang berwenang. Ketentuan tersebut sesuai pula dengan ketentuan yang diatur dalam pasal 48 ayat (2) yang menyatakan "pengadilan baru berwenang memeriksa, menyelesaikan sengketa Tata Usaha Negara sebagaiman dimaksud dalam ayat (1) jika seluruh upaya administratif yang bersangkutan telah digunakan " jo ketentuan pasal 51 ayat (3) ditentukan bahwa dalam hal suatu sengketa dimungkinkan adanya administratif maka gugatan langsung ditujukan kepada Pengadilan Tinggi Tata Usaha Negara apabila keputusannya merupakan keputusan banding administratif.

\section{BAB III}

\section{PENUTUP}

Berdasarkan uraian tersebut diatas, maka dapat disimpulkan hal-hal sebagai berikut :

1. Apakah suatu sengketa Tata Usaha Negara harus diselesaikan melalui upaya administrasi atau tidak, adalah tergantung padaperaturan perundang-undangan yang menjadi dasar mengeluarkan keputusan Tata Usaha Negara tersebut

2. Istilah upaya administratif hanya ada dalam Undang-Undang No. 5 tahun 1986 jo UndangUndang No 9 Tahun 2004 tentang Peradilan Tata Usaha Negara, sedangkan peraturan perundang-undangan memakai istilan yang bermacam-macam;

3. Untuk membedakan apakah sengketa harus diselesaikan melalui banding administratif atau keberatan dapat dilihat dari pejabat atau instansi yang berwenang menyelasaikannya; a. Apabila 
diselesaikan oleh instansi atasan Pejabat yang menerbitkan Keputusan Tata Usaha Negara tersebut atau instansi yang lainnya dari Badan/Pejabat Tata Usaha Negara yang menerbitkan Keputusan Tata Usaha Negara, maka penyelesaiannya tersebut disebut dengan "BANDING ADMINISTRATIF"; b. Apabila diselesaikan instansi atau Pejabat yang mengeluarkan keputusan Tata Usaha Negara tersebut, penyelesaian tersebut disebut dengan "KEBERATAN".

4. Cara pengujian penyelesaian melalui upaya administratif adalah dilakukan secara lengkap dalam arti dari segi hukum dan kebijaksanaan, sedangkan pengujian di Pengadilan hanya dari segi hukumnya saja;

5. Dalam hal masih tidak puas terhadap penyelesaian melalui upaya administratif, maka dapat ditempuh upaya antara lain :

a. Setelah melalui upaya administratif maka dapat diajukan gugatan ke Pengadilan Tinggi Tata Usaha Negara sebagai pengadilan tingkat pertama;

b. Setelah melalui upaya keberatan, maka dapat diajukan ke Pengadilan Tata Usaha Negara.

BAB IV

DAFTAR PUSTAKA

Darmini Roza dan Laurensius Arliman S Peran Pemerintah Daerah Di Dalam Melindungi Hak Anak Di Indonesia, Masalah-Masalah Hukum, Volume 47, Nomor 1, 2018.

Laurensius Arliman S, Komnas HAM dan Perlindungan Anak Pelaku Tindak Pidana, Deepublish, Yogyakarta, 2015.

Laurensius Arliman S, Penguatan Perlindungan Anak Dari Tindakan Human Trafficking Di Daerah Perbatasan Indonesia, Jurnal Selat, Volume 4, Nomor 1, 2016.

Laurensius Arliman S, Problematika Dan Solusi Pemenuhan Perlindungan Hak Anak Sebagai Tersangka Tindak Pidana Di Satlantas Polresta Pariaman, Justicia Islamica, Volume 13, Nomor 2, 2016. 
Laurensius Arliman S, Pelaksanaan Perlindungan Anak Yang Tereksploitasi Secara Ekonomi Oleh Pemerintah Kota Padang, Veritas et Justitia, Volume 2, Nomor 1, 2016.

Laurensius Arliman S, Kedudukan Ketetapan MPR Dalam Hierarki Peraturan Perundang-Undangan Di Indonesia, Lex Jurnalica, Volume 13, Nomor 3, 2016.

Laurensius Arliman S, Komnas Perempuan Sebagai State Auxialiary Bodies Dalam Penegakan Ham Perempuan Indonesia, Justicia Islamica, Volume 14, Nomor 2, 2017.

Laurensius Arliman S, Peranan Pers Untuk Mewujudkan Perlindungan Anak Berkelanjutan Di Indonesia, Jurnal Ilmu Hukum Tambun Bungai, Volume 2, Nomor 2, 2017.

Laurensius Arliman S, Mewujudkan Penegakan Hukum Yang Baik Untuk Mewujudkan Indonesia Sebagai Negara Hukum, Jurnal Hukum Doctrinal, Volume 2, Nomor 2, 2017.

Laurensius Arliman S, Participation Non-Governmental Organization In Protecting Child Rights In The Area Of Social Conflict, The 1st Ushuluddin and Islamic Thought International Conference (Usicon), Volume 1, 2017.

Laurensius Arliman S, Partisipasi Masyarakat Dalam Pembentukan Perundang-Undangan Untuk Mewujudkan Negara Kesejahteraan Indonesia, Jurnal Politik Pemerintahan Dharma Praja, Volume 10, Nomor 1, 2017, https://doi.org/10.33701/jppdp.v10i1.379.

Laurensius Arliman S, Peran Komisi Perlindungan Anak Indonesia Untuk Mewujudkan Perlindungan Anak, Jurnal Respublica Volume 17, Nomor 2, 2018.

Laurensius Arliman S, Menjerat Pelaku Penyuruh Pengrusakan Barang Milik Orang Lain Dengan Mempertimbangkan Asas Fungsi Sosial, Jurnal Gagasan Hukum, Volume 1, Nomor 1, 2019. 
Laurensius Arliman S, Ilmu Perundang-Undangan Yang Baik Untuk Negara Indonesia, Deepublish, Yogyakarta, 2019.

Laurensius Arliman S, Isdal Veri, Gustiwarni, Elfitrayenti, Ade Sakurawati, Yasri, Pengaruh Karakteristik Individu, Perlindungan Hak Perempuan Terhadap Kualitas Pelayanan Komnas Perempuan Dengan Kompetensi Sumber Daya Manusia Sebagai Variabel Mediasi, Jurnal Menara Ekonomi: Penelitian dan Kajian Ilmiah Bidang Ekonomi, Volume 6, Nomor 2, 2020.

Laurensius Arliman S, Pendidikan Kewarganegaraan, Deepublish, Yogyakarta, 2020.

Laurensius Arliman S, Makna Keuangan Negara Dalam Pasal Pasal 23 E Undang-Undang Dasar 1945, Jurnal Lex Librum, Volume 6, Nomor 2 Juni 2020, http://dx.doi.org/10.46839/Iljih.v6i2.151.

Laurensius Arliman S, Kedudukan Lembaga Negara Independen Di Indonesia Untuk Mencapai Tujuan Negara Hukum, Kertha Semaya Journal IImu Hukum, Volume 8, Nomor 7, 2020.

Laurensius Arliman S, Pelaksanaan Assesment Oleh Polres Kepulauan Mentawai Sebagai Bentuk Pelaksanaan Rehabilitasi Bagi Pecandu Dan Korban Penyalahgunaan Narkotika, Jurnal Muhakkamah, Volume 5, Nomor 1, 2020.

Laurensius Arliman S, Aswandi Aswandi, Firgi Nurdiansyah, Laxmy Defilah, Nova Sari Yudistia, Ni Putu Eka, Viona Putri, Zakia Zakia, Ernita Arief, Prinsip, Mekanisme Dan Bentuk Pelayanan Informasi Kepada Publik Oleh Direktorat Jenderal Pajak, Volume 17, No Nomor, 2020.

Larensius Arliman S, Koordinasi PT. Pegadaian (Persero) Dengan Direktorat Reserse Narkoba Polda Sumbar Dalam Penimbangan Barang Bukti Penyalahgunaan Narkotika, UIR Law Review, Volume 4, Nomor 2, 2020, https://doi.org/10.25299/uirlrev.2020.vol4(1).3779.

Laurensius Arliman S, Tantangan Pendidikan Kewarganegaraan Pada Revolusi 4.0, Ensiklopedia Sosial Review, Volume 2, Nomor 3, 2020. 
Muhammad Afif dan Laurensius Arliman S, Protection Of Children's Rights Of The Islamic And Constitutional Law Perspective Of The Republic Of Indonesia, Proceeding: Internasional Conference On Humanity, Law And Sharia (Ichlash), Volume 1, Nomor 2, 2020.

Otong Rosadi danLaurensius Arliman S, Urgensi Pengaturan Badan Pembinaan Idelogi Pancasila Berdasarkan Undang-Undang Sebagai State Auxiliary Bodies yang Merawat Pancasila dalam Perspektif Hak Asasi Manusia, Prosiding Konferensi Nasional Hak Asasi Manusia, Kebudayaan dan Tujuan Pembangunan Berkelanjutan Indonesia pada Masa Pandemi Covid-19: Tantangan untuk Keilmuan Hukum dan Sosial Volume 1, Universitas Pancasila, Jakarta, 2020. 